Статівка Н.В., д.держ.упр., проф., ХАРІДУ НАДУ при Президентові Украӥни, м. Харків, ORCID: 0000-0003-0903-6256,

Гордієнко С.П., аспірант ХАРІДУ НАДУ при Президентові України, м. Харків, ORCID: 0000-0001-5939-433X

Stativka N., Doctor of Public Administration, Professor, Kharkiv Regional Institute of Public Administration, National Academy of Public Administration at the President of Ukraine, Kharkiv,

Hordiienko Ye., Postgraduate Student, Department of Personnel Management and Labor Economics, Kharkiv Regional Institute of Public Administration, National Academy of Public Administration at the President of Ukraine, Kharkiv

\title{
СОЦАЛЬНО-ЕКОНОМІЧНЕ ЗАБЕЗПЕЧЕННЯ РЕАЛІЗАЦІЇ ДЕРЖАНОЇ ПОЛІТИКИ У СФЕРІ СОЦІАЛЬНОГО ЗАХИСТУ УЧАСНИКІВ БОЙОВИХ ДІЙ
}

\section{SOCIO-ECONOMIC SUPPORT FOR THE IMPLEMENTATION OF THE STATE POLICY IN THE FIELD OF COMBATANTS' SOCIAL PROTECTION}

У статті досліджено сучасний стан сочіально-економічного забезпечення реалізаџї державної політики сочіального захисту учасників бойових дій. Наведено механізм здійснення державної політики сочіального захисту учасників бойових дій через фінансову складову сочіально-економічного механізму, проаналізовано використання державних коштів за 2018-2020 роки на основні державні програми сочіального захисту учасників бойових дій. Визначені основні проблемні питання соціальноекономічного забезпечення сочіального захисту учасників бойових дій та можливі шляхи їх вирішення.

Ключові слова: державна політика, соціальний захист, учасник бойових дій, сочіально-економічний механізм, фінансове забезпечення, фінансове регулювання, державні сочіальні програми.

The article examines the current state of socio-economic support for the implementation of state policy of combatants' social protection. The mechanism of implementation of the state policy of combatants' social protection through the financial component of the socio-economic mechanism has been presented, the use of state funds for 2018-2020 for the main state programs of combatants' social protection has been analyzed. The main problematic issues of socio-economic support of combatants' social protection and possible ways to solve them have been identified.

Key words: state policy, social protection, combatant, socio-economic mechanism, fi- 
nancial support, financial regulation, state social programs.

Постановка проблеми. Уряди, приходячи до влади, пропонують суспільству політику розвитку країни та окремих ії̈ сфер, метою якої є підвищення рівня життя та добробуту населення країни. Понад 6 років в Україні ведуться бойові дії. Статус учасника бойових дій (далі-УБД), який станом на квітень 2021 р. отримали понад 460 тис. осіб, надає право на соціальний захист шляхом створення належних умов життєдіяльності, виконання цільових програм, надання пільг, переваг та соціальних гарантій. Процес розвитку системи соціального захисту військовослужбовців і ветеранів в Україні, що забезпечується оновленням законодавчої бази, удосконаленням інституційного забезпечення та запровадженням стандартів НАТО, є складовим процесу досягнення високого рівня обороноздатності держави. Ефективність політики соціального захисту УБД, насамперед, залежить від рівня фінансування, своєчасного та повного фінансового забезпечення соціальних виплат і цільових державних програм.

Забезпечення ефективності реалізації державної політики у сфері соціального захисту військовослужбовців в умовах обмеженості ресурсів, вимагає побудови дієвого соціально-економічного механізму з чітким формулювання кінцевої мети, виокремленням ключових функції, системи моніторингу соціально-економічних проблем та оцінювання ефективності використання державних коштів. Сучасна політика соціального захисту має спиратися на прогнозні показники реального розвитку економіки, ресурсні та фінансові можливості держави. Аналіз державних видатків та використання державних коштів на соціальний захист ветеранів дозволить сфокусувати увагу на окремих управлінських рішеннях та діях щодо учасників бойових дій, розкрити їх нагальність, раціональність та забезпечити дієвість.

Аналіз останніх досліджень і публікацій. Державна політика соціального захисту населення постійно перебуває у колі наукових інтересів дослідників i носить переважно міждисциплінарний характер. Глибокі дослідження проблем формування та функціонування механізмів державного управління, зокрема фінансового та соціально-економічного, представлені у працях Л. Б. Баранник， А. О. Спіфанова， О. М. Жука， Л.М.Ільїч， В. П. Москаленко, А. Ю. Огінської, Н. Г. Савченко, О.В.Шипунова, Л. М. Худолій та ін. Незважаючи на широкий спектр наукових розробок щодо механізмів державного управління, дослідження комбінованих механізмів соціального захисту учасників бойових дій (фінансово-економічних, соціально-економічних, організаційноекономічних та інших) зустрічається лише в окремих працях таких вчених, як I. М. Гайда, В. А. Кучер, О. О. Кондратенко.

Постановка завдання. Метою статті є дослідження теоретичних і практичних аспектів соціально-економічного забезпечення реалізації державної по- 
літики соціального захисту учасників бойових дій, виокремлення фінансової складової зазначеного механізму та аналіз використання державних коштів.

Виклад основного матеріалу. Кожна економічна система вибудовується задля координації діяльності іiі суб'єктів 3 метою вирішення їх соціальноекономічних проблем та реалізації конкретних економічних інтересів. Поняття «соціально-економічний механізм» поширювалося по мірі набуття в механізмах розподілу ресурсів національних систем ознак соціальної економіки. Стосовно соціального захисту УБД сутність соціально-економічного механізму являє собою специфічний, якісно визначений вплив держави засобами і методами регулювання, що поєднують прямий і зворотний зв'язок та визначають можливість цілеспрямованого руху, функціонування й розвитку керованої системи задля реалізацій цілей політики соціального захисту УБД. В свою чергу, соціальна складова механізму направлена на створення належних умов та задоволення соціальних потреб УБД. Економічна складова механізму забезпечує формування і визначення сприятливих умов розвитку економічного потенціалу країни й підвищення ефективності його використання, а також надання державної фінансової допомоги ветеранам. Доречно виокремити важливість фінансової складової в процесі реалізації політики соціального захисту УБД. Від рівня фінансування, своєчасного та повного фінансового забезпечення соціальних виплат та цільових державних програм, направлених на допомогу у вирішенні ключових соціальних питань, залежить якість та своєчасність медичної та психологічної реабілітації, забезпеченість житлом, грошова допомога, соціальна та професійна адаптації УБД.

Фінансовий вплив на соціально-економічний розвиток, який лежить в основі формування і реалізації фінансової політики, здійснюється через фінансовий механізм [1]. Зазначимо, що фінансовий механізм можна розглядати як складову частину соціально-економічного механізму. Це цілий комплекс елементів, підсистем, кожна з яких має свої методи та інструменти, що комплексно взаємодіють та взаємодоповнюють один одного.

Термін «фінансовий механізм системи соціального захисту населення» зустрічається лише в окремих працях науковців. На нашу думку, фінансовий механізм реалізації державної політики соціального захисту УБД це сукупність фінансових форм і методів, важелів та інструментів, за допомогою яких здійснюється формування, перерозподіл і використання фінансових ресурсів для досягнення поточних завдань і кінцевої мети обраної політики, а саме забезпечення добробуту та задоволення життєво необхідних потреб УБД (рис.1). Можемо виділити дві найважливіші підсистеми фінансового механізму: фінансове забезпечення і фінансове регулювання, які взаємопов'язані між собою. Підсистема фінансового забезпечення може бути представлена у формах: самофінансування, спільного фінансування, кредитування, зовнішнього фінансування. Кож- 
на $з$ вищезазначених форм має свої особливості та умови практичного застосування. Самофінансування являє собою забезпечення соціальних потреб УБД за рахунок власних коштів та передбачає розрахунок ефективності та доцільності їх витрачання. Ця форма фінансового забезпечення серед УБД представлена рідко, що свідчить про низьке грошове забезпечення та рівень життя населення. Спільне фінансування заходів щодо соціального захисту УБД (реабілітація, санаторно-курортні послуги, оздоровлення тощо) може здійснюватись за спільні кошти бюджету (державного/місцевого) та підприємств, організацій, міжнародної спільноти тощо. Ця форма використовується для реалізації багатьох заходів та програм соціального захисту УБД на регіональному та міжнародному рівнях.

Підсистема фінансового регулювання полягає у регламентуванні розподільних відносин у суспільстві та здійснюється методами прямого (бюджетне фінансування, державне інвестування, пільгове кредитування) та непрямого регулювання (податкові ставки) [2, с. 249-265]. Засобами фінансового регулювання $є$ фінансові інструменти та важелі. Враховуючи структуру соціального захисту УБД, фінансовий механізм соціального захисту включає в себе такі інструменти, як: соціальне страхування, соціальне забезпечення, соціальна допомога, соціальні гарантії та компенсації, які в свою чергу мають свої автономні фінансові механізми, закріплені законодавством.

Фінансові важелі, зокрема соціальні норми, пільги, гарантії та компенсації $\epsilon$ важливим елементом фінансового механізму. Щодо УБД та членів їх сім’ї, відповідно до Закону України «Про статус ветеранів війни, гарантії їх соціального захисту» запроваджено низку соціальних пільг та соціальних гарантій [3]. На сьогодні пільгова система здебільшого має компенсаторний, а не мотивувальний характер та не забезпечує гідного рівня життя УБД. Крім того, виникають складнощі у фінансуванні окремих видів пільг, гарантій та компенсацій УБД.

Отже, головне призначення фінансової складової соціально-економічного механізму соціального захисту УБД полягає у створенні реальної фінансової бази та ефективному формуванні та використанні фінансових ресурсів.

Соціально-економічний механізм передбачає формування джерел фінансових ресурсів усіх економічних агентів, які дозволені законодавством. Основним джерелом фінансових ресурсів виступає валовий внутрішній продукт (далі - ВВП). В процесі розподілу та перерозподілу ВВП формуються централізовані (державний та місцевий бюджети, соціальні фонди) та децентралізовані фонди фінансових ресурсів (фонди загальнообов'язкового державного соціального страхування), а також недержавні соціальні фонди (кошти підприємств, організацій, інші благодійні кошти тощо). 


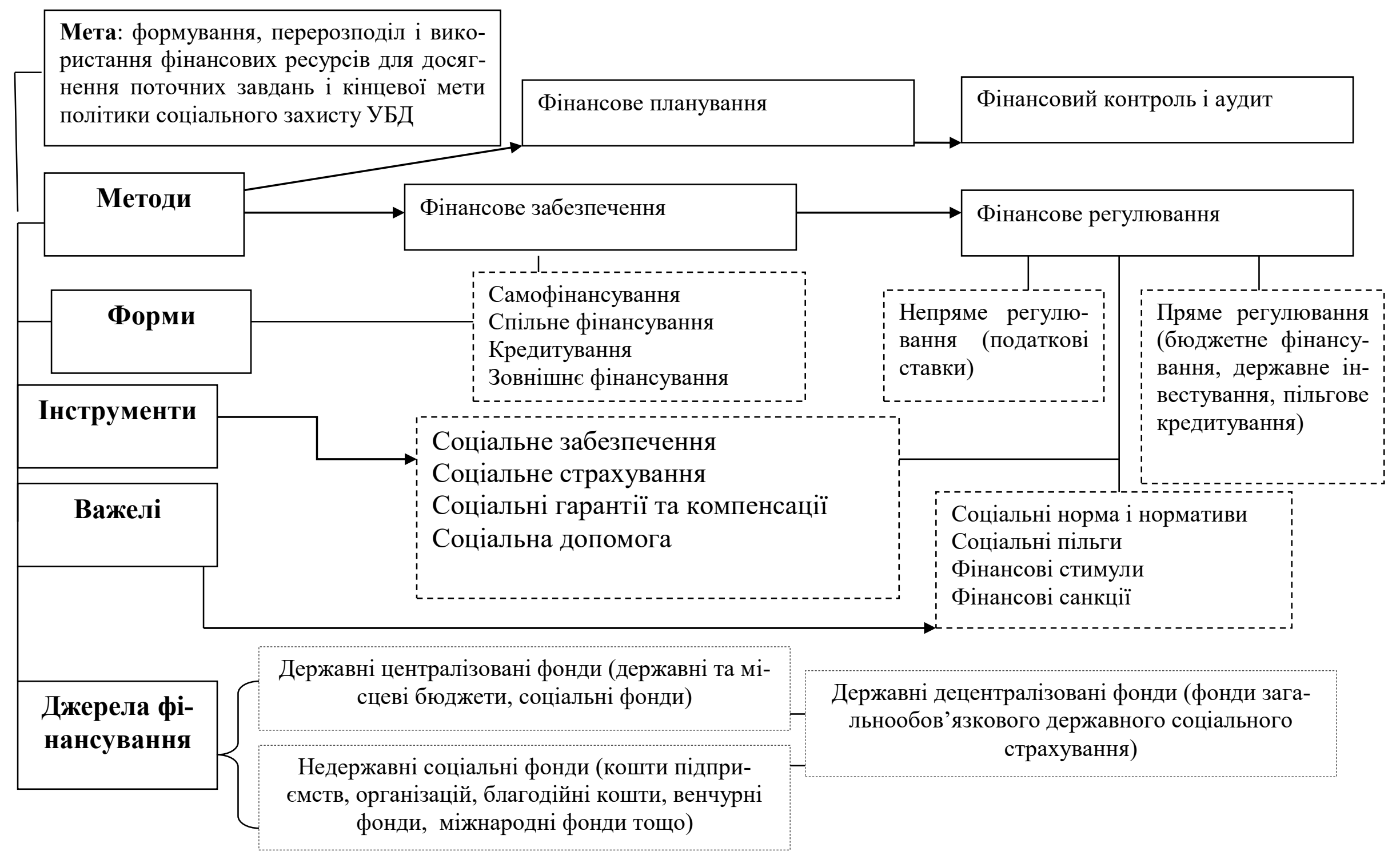

Рис. 1 Фінансовий механізм реалізації державної політики соціального захисту УБД (складено автором) 
Фінансування системи соціального захисту УБД здійснюється відповідно до бюджетного законодавства, зокрема Бюджетного Кодексу України [4], законами про державні бюджети України та визначається ст. 17 Закону України «Про статус ветеранів війни, гарантії їх соціального захисту» [3]. 3 початком бойових дій на території України, сфера оборони та соціального захисту УБД є однією з найбільш видаткових статей зведеного бюджету України. Доречно здійснити аналіз динаміки соціальних видатків з Державного бюджету України на соціальний захист ветеранів упродовж 2014-2020 pр. (табл. 1).

Таблиця 1

Динаміка показників обсягів річних видатків на соціальний захист ветеранів війни в Україні впродовж 2014-2020 роки [9]

\begin{tabular}{|c|c|c|c|}
\hline Роки & $\begin{array}{c}\text { Видатки на соціальний за- } \\
\text { хист ветеранів війни, млн. } \\
\text { грн. }\end{array}$ & $\begin{array}{c}\text { у \% до загальної суми } \\
\text { зведеного бюджету }\end{array}$ & $\mathrm{y} \%$ до ВВП \\
\hline 2014 & 1624,5 & 0,42 & 0,10 \\
\hline 2015 & 2644,7 & 0,47 & 0,13 \\
\hline 2016 & 3086,6 & 0,48 & 0,13 \\
\hline 2017 & 3428,3 & 0,45 & 0,12 \\
\hline 2018 & 4108,3 & 0,45 & 0,12 \\
\hline 2019 & 82367,0 & 8,37 & 2,07 \\
\hline 2020 & 90148,6 & 7,94 & - \\
\hline
\end{tabular}

*Сума обрахована шляхом додатку коштів, передбачених бюджетними програмами Державних бюджетів України 2014-2020 років

Аналізуючи обсяги річних видатків на соціальний захист ветеранів війни в період ведення бойових дій, можемо зробити певні висновки. На початку ведення війни видатки збільшились на 1020,2 млн. грн., поступово зростаючи впродовж наступних чотирьох років. При цьому впродовж 20152018 pp. їх питома вага у загальній сумі зведеного бюджету майже не змінювались і коливалася в межах 0,45-0,48 \%. Істотне збільшення видатків на соціальний захист військовослужбовців та ветеранів відбулося у 20192020 рр., частка яких зросла відповідно до 8,37 та 7,94 \% від загальної суми зведеного бюджету та склала 2,07\% ВВП (2019 р.). Це може свідчити про політичну вмотивованість щодо вирішення проблеми соціального забезпечення та захисту ветеранів. Переконливим доказом є створення у 2018 p. Міністерства у справах ветеранів (далі - Мінветеранів). Задля подолання диспропорцій у грошовому забезпеченні військовослужбовців, у тому числі УБД, з 2019 р. було збільшено видатки на забезпечення діяльності Збройних сил, медичне лікування, реабілітацію та санаторне забезпечення особового складу Збройних сил і ветеранів війни. У 2020 році у середньому на соціа- 
льний захист одного УБД держава виділяла 13 тис. грн на рік.

Не зважаючи на високий рівень видатків, експерти звертають увагу на недосконалість соціально-економічного механізму, що не дає змогу на практиці забезпечити високий рівень соціального захисту УБД [5].

Проаналізуємо використання державних коштів за 2018-2020 pp. на основні державні програми підтримки УБД, дослідивши фактичний стан та результативні показники виконання бюджетних програм Мінветеранів, Miністерства соціальної політики та Міністерства оборони України щодо соціального захисту ветеранів, а саме УБД (табл. 2).

Таблиця 2

Аналіз використання коштів на бюджетні програми соціального захисту ветеранів-УБД за 2018-2019 роки (млн. гривень) $[6,7,8]$

\begin{tabular}{|c|c|c|c|c|c|c|c|c|c|}
\hline \multirow[t]{2}{*}{ КПКВК } & \multicolumn{3}{|c|}{2018 p. } & \multicolumn{3}{|c|}{2019 p. } & \multirow{2}{*}{$\begin{array}{c}2020 \text { p. } \\
\text { план }\end{array}$} & \multicolumn{2}{|c|}{$\begin{array}{c}\text { Відхилення } \\
\text { плану } 2020 \text { р. } \\
\text { від } 2019 \text { р. }\end{array}$} \\
\hline & план & факт & $\%$ & план & факт & $\%$ & & $+/-$ & $\%$ \\
\hline $\begin{array}{l}21010802 \\
101020\end{array}$ & 2161,1 & 2161,1 & 100,0 & 58069,2 & 58125,9 & 100,0 & 62739,5 & 4613,6 & 108,0 \\
\hline 2501150 & 1303,1 & 1302,2 & 99,9 & 1324,8 & 1323,9 & 99,9 & 1382,5 & 58,6 & 104,4 \\
\hline 2501470 & 176,1 & 175,9 & 99,8 & 206,8 & 197,7 & 95,6 & 207,4 & 9,7 & 104,9 \\
\hline $\begin{array}{l}2505150 \\
1501040\end{array}$ & 109 & 107,2 & 98,3 & 112,7 & 109,1 & 96,8 & 246,4 & 137,3 & 225,8 \\
\hline $\begin{array}{l}2505030 \\
1501030\end{array}$ & 8,7 & 5,6 & 64,4 & 9,0 & 7,4 & 82,2 & 8,6 & 1,2 & 116,2 \\
\hline
\end{tabular}

* за загальним фондом Державного бюджету

Медичне забезпечення та реабілітація, протезування військовослужбовців, у тому числі УБД здійснювалось за програмою КПКВК 2101080 у 2018 р. та КПКВК 2101020 (п.1, п.12) у 2019-2020 рр. Головним розпорядником коштів за даною програмою є Міністерство оборони України. У 2018 та 2019 роках програми виконано на 100\%.

Виплата щорічної разової грошової допомоги до 5 травня здійснюється на підставі бюджетної програми КПКВК 2501150, розпорядником коштів якої $є$ Міністерство соціальної політики. Щороку обсяг видатків на виконання цієї бюджетної програми зростає. За результатами виконання 2018 р. і 2019 р. програму виконано на 99,9 \%. Загальна кількість УБД, що отримали допомогу в 2018 р. становила 455,8 тис. осіб, у 2019 р. $-469,8$ тис. осіб, що засвідчує збільшення кількості осіб, що отримують ці виплати.

Розмір щорічної разової грошової допомоги УБД:

2018 рік $=1265$ гривень

2019 рік $=1295$ гривень

2020 рік $=1390$ гривень

$\left\{\begin{array}{l}30 \text { гривень } \\ 95 \text { гривень }\end{array}\right.$

Санаторно-курортне лікування ветеранів війни здійснюється на підставі бюджетної програми КПКВК 2501470, фінансування якої поступово 214 
збільшується з кожним роком. Однак частка осіб (у загальній кількості осіб, що звернулись), які отримують санаторно-курортне лікування за цією програмою у 2019 р. порівняно до попереднього року, зменшилась на 0,9 в.п. та складала 34,9 \% (17716 осіб). Це свідчить про збільшення кількості ветеранів, які потребують санаторно-курортного лікування [7]. Санаторнокурортне лікування УБД закладено в інших бюджетні програмах. На жаль, офіційні звіти про виконання паспортів бюджетних програм та інша інформація, розміщена на офіційних веб-сайтах державних органів не дає можливості виявити чи всі УБД, які потребують санаторно-курортного лікування, забезпечені цією послугою. Розгалужена система не дає повністю оцінити рівень санаторно-курортного забезпечення УБД. Крім того, велика частина коштів бюджетної програми витрачається на придбання обладнання та інші потреби санаторіїв.

Видатки на психологічну реабілітацію, соціальну та професійну адаптацію УБД затверджуються щорічно починаючи з 2014 р. Кошти на відповідні заходи у 2018 р. були передбачені бюджетною програмою КПКВК 2505150, з 2019 р. КПКВК 1501040. Урядом затверджено Державну цільову програму з медичної, фізичної реабілітації та психосоціальної реадаптації постраждалих учасників Революції Гідності, учасників антитерористичної операції та осіб, які брали участь у здійсненні заходів із забезпечення національної безпеки і оборони, відсічі і стримування збройної агресії Російської Федерації в Донецькій та Луганській областях, забезпеченні їх здійснення, на період до 2023 року, що фінансується в межах зазначених бюджетних програм та інших бюджетних програм. Обсяг видатків у 2019 р. становив 112,7 млн. грн, а у 2020 р. - 506,8 млн. грн. Орієнтовний обсяг видатків на 2021 р. - 449,5 млн. грн, 2022 р. - 462,8, 2023 р. - 320,1 млн. грн. [10].

У програмах психологічної реабілітації взяли участь УБД кількісно у 2018 р. 2704 особи, у 2019 р. - 2278, у 2020 р. - 6541 особа. Чисельність осіб УБД, які потребують психологічної реабілітації, постійно зростає. Середні витрати на одного УБД у 2018 р. складали 7481,2 грн, у 2019 р. - 9310,5 грн [7]. У 2020 р. вони зросли до 11529 грн, що на 54,1\% більше рівня 2018 р. Психологічну допомогу УБД надають центри соціально-психологічної реабілітації, фінансування яких є одним із напрямків бюджетної програми. Подальша популярність послуги залежить від рівня інформаційного забезпечення УБД, а також від налагодження обліку кількості осіб, які потребують психологічної реабілітації. Також важливим є підготовка фахівців у сфері психологічної реабілітації та залучення спеціалістів, які мають відповідний фах і досвід роботи з наслідками психологічної травматизації. Середні витрати, пов'язані із соціальною та професійною адаптацією УБД, в розрахунку на одного у 2018 р. становили 5528,2 грн, у 2019 р. - 6209 грн, збільшившись до 7656,1 грн у 2020 р. [8]. Для підвищення результативності програми потрібно розширити спектр напрямів психологічної допомоги та професійної підготовки. 
Фінансова підтримка громадських об’єднань ветеранів-УБД здійснюється в рамках бюджетної програми КПКВК 1501030, яка у 2018 р. реалізовувалася Міністерством соціальної політики (КПКВК 2505030), а 32019 р. головним розпорядником коштів стало Мінветеранів. Обсяг фінансової підтримки громадських об'єднань ветеранів у 2019 р. зменшився на 0,3 млн. грн порівняно з попереднім роком. Виконання програми лише на 64,4 \% у 2018 р. було пов'язано переважно із запровадженням надання фінансової підтримки за результатами конкурсного відбору більш актуальних програм, проектів та заходів. Так, у 2018 р. 14 громадських об'єднань ветеранів отримали фінансову підтримку, у 2019 р. - 12, а вже у 2020 р. фінансову підтримку надали 22 громадським об'єднанням ветеранів війни [8]. Подальша підтримка громадських об'єднань надасть змогу встановити зв'язок між владою та ветеранською спільнотою.

В України на регіональному рівні діють багато цільових програм соціального захисту населення, що містять окремі заходи щодо захисту УБД. Серед особливостей регіональних програм можемо виділити: фінансування соціальних таксі, розширення мережі ветеранських аптек, соціальний захист добровольців, додаткова грошова допомога УБД, спортивна реабілітація УБД, відкриття власного бізнесу УБД, підтримка громадських ветеранських організацій, забезпечення соціальної підтримки членів сімей осіб, зниклих безвісти за особливих обставин. На нашу думку, державні програми є потужним інструментом покращення соціальних умов для ветеранів в рамках реалізації державної політики соціального захисту УБД, за умови ефективного використання коштів та залучення додаткових джерел фінансування.

Міжнародна практика свідчить про наявність у багатьох країн потужної фінансової підтримки з боку недержавних соціальних фондів, а саме благодійних фондів, венчурних фондів та міжнародних фондів. Щодо України, поступово розвивається благодійна діяльність та з'являються потужні міжнародні проекти для підтримки УБД. На сьогодні діють три міжнародні проекти: проект Європейського союзу «Підтримка реінтеграції ветеранів конфлікту на Сході України» з загальним бюджетом 3000 тис. євро; проект США «Програма реінтеграції ветеранів» з загальним бюджетом 5037 тис. дол. США; проект ОБСС «Соціальна та психологічна реабілітація населення, що постраждало внаслідок конфлікту» з загальним бюджетом 85 тис. євро [8].

В контексті фінансування системи соціального захисту УБД в Україні, крім бюджетних та міжнародних коштів, потрібно й надалі розвивати та використовувати такі джерела, як: власні кошти громадян та громадські ініціативи (різні фонди, збори); венчурні фонди; відшкодування та відстрочки; кошти підприємств (у вигляді їх зобов'язань щодо виконання соціальних функцій) та бізнес структур; надання державного майна для функціонування соціальної сфери, використання державної інфраструктури та інше.

Висновки. Дослідивши теоретичні та практичні аспекти функціонування соціально-економічного механізму реалізації державної політики со- 
ціального захисту УБД можемо висновувати. По-перше, розвиток системи соціального захисту військовослужбовців, у тому числі УБД, повинен розпочатись 3 відповідного нормативного закріплення всіх складових соціально-економічного механізму та удосконалення законодавства щодо соціального захисту УБД. По-друге, необхідно вжити заходів для: 1) покращення соціальних умов, в яких функціонує УБД; 2) спрямування бюджетних коштів на пріоритетні напрями соціального захисту УБД; 3) створення реальної фінансової бази та залучення інших джерел фінансування; 4) підвищення рівня інформаційного забезпечення УБД та встановлення зв'язку між владою та ветеранським суспільством; 5) удосконалення моніторингу використання коштів; 6) створення трирівневої системи психологічної, медичної та соціальної допомоги, організованої на місцевому, регіональному та національному рівнях з відповідним фінансовим механізмом; 7) розвитку економічного стимулювання, надання податкових пільг, кредитування з бюджетів та соціальних фондів на здійснення соціального захисту УБД; 8) залучення бізнесу та розвитку соціального партнерства.

Також, в умовах невизначеної тривалості конфлікту та подальшого проведення Операції об'єднаних сил, потрібно застосовувати нові підходи для удосконалення соціально-економічного забезпечення державної політики соціального захисту УБД та підвищення результативності використання державних коштів. Ефективне використання соціально-економічних ресурсів виведе політику соціального захисту УБД на новий рівень та забезпечить залучення до лав армії мотивованого контингенту населення.

\section{Список використаних джерел:}

1. Аналітичний звіт. Стан виконання бюджетних програм з питань соціального захисту учасників війни України проти російської агресії. Юридична сотня. URL: https://legal100.org.ua/wp-content/uploads/2018/06/budjetu-2018.pdf (дата звернення: 24.03.2021)

2. Бюджетний кодекс України: Закон України від 08.07.2010 № 2456-VI (Редакція станом на 04.07.2020). URL: https://zakon.rada.gov.ua/laws/show/245617\#Техt (дата звернення: 10.04.2021)

3. Офіційний сайт Міністерства оборони України. URL: https://www.mil.gov.ua/ (дата звернення: 14.03.2021)

4. Офіційний сайт Міністерства у справах ветеранів України. URL: https://mva.gov.ua/ua (дата звернення: 15.03.2021)

5. Офіційний сайт Міністерства фінансів України. URL: https://index.minfin.com.ua/ua/finance/budget/gov/ (дата звернення: 03.03.2021)

6. Паспорти бюджетних програм на 2020 рік. Міністерство соціальної політики в України. URL: https://www.msp.gov.ua/news/18260.html (дата звернення 24.04.2021)

7. Про затвердження Державної цільової програми з медичної, фізичної реабілітації та психосоціальної реадаптації постраждалих учасників Революції Гідності, учасників антитерористичної операції та осіб, які брали участь у здійсненні заходів із забезпечення національної безпеки і оборони, відсічі і стримування 
збройної агресії Російської Федерації в Донецькій та Луганській обл., забезпеченні їх здійснення, на період до 2023 р.: постанова КМУ від 05.12.2018 №1021. URL: https://zakon.rada.gov.ua/laws/show/1021-2018-\%D0\%BF\#Text (дата звернення: 20.04.2021).

8. Про статус ветеранів війни, гарантії їх соціального захисту: Закон України від 22 жовтня 1993 р. № 3551-XII. URL: https://zakon.rada.gov.ua/laws/show/3551-12 (дата звернення: 12.04.2021)

9. Фінанси: підручник / За ред. С. І. Юрія, В. М. Федосова. К.: Знання, 2008. $611 \mathrm{c}$.

10. Фінансово-економічний механізм ефективного функціонування аграрних підприємств України. Монографія. /За редакцією д. е. н., проф. Л.М. Худолій. К.:ЦП “ КОМПРИНТ ”, 2017. С. 249-265.

\section{References:}

1. Analytical report. The state of implementation of budget programs on social protection of participants in the war of Ukraine against Russian aggression. Legal hundred. Web. 21 March 2021. <https://legal100.org.ua/wpcontent/uploads/2018/06/budjetu-2018.pdf>

2. Ukraine. Verkhovna Rada of Ukraine. Budget Code of Ukraine. N.p., 08 $\begin{array}{llllll}\text { June } & 2010 \quad \text { № } & \text { 2456-VI. } & \text { Web. } & 10 & \text { april }\end{array}$ https://zakon.rada.gov.ua/laws/show/2456-17\#Text>

3. Official website of the Ministry of Defense of Ukraine. Web 14 March 2021. <https://www.mil.gov.ua/>

4. Official website of the Ministry of Veterans Affairs of Ukraine. Web 15 March 2021. <https://mva.gov.ua/ua>

5. Official website of the Ministry of Finance of Ukraine. Web 03 March 2021. <https://mva.gov.ua/ua>

6. Passports of budget programs for 2020. Ministry of Social Policy in Ukraine. Web. 24 april 2021. <https://www.msp.gov.ua/news/18260.html>

7. Ukraine. Verkhovna Rada of Ukraine. Resolution of the Cabinet of Ministers of Ukraine: On approval of the State Target Program for Medical, Physical Rehabilitation and Psychosocial Rehabilitation of Victims of the Revolution of Dignity, Participants in the Anti-Terrorist Operation and Persons Who Participated in Measures to Ensure National Security and Defense, Repel and Restrain Armed Aggression of the Russian Federation in Donetsk and Luhansk areas, ensuring their implementation, for the period up to 2023. N.p., 05.12.2018 №1021. Web. 20 april $2021 .<$ https://zakon.rada.gov.ua/laws/show/1021-2018-\%D0\%BF\#Text>

8. Ukraine. Verkhovna Rada of Ukraine. On the status of war veterans, guarantees of their social protection. N.p., 22 October 1993 № 3551-XII. Web. 12 april 2021. < https://zakon.rada.gov.ua/laws/show/3551-12>

9. Yuri, S.I., Fedosov, V.M. Finance [Finansy]. Kiev, 2008. 611 p.

10. Khudoliy, L. M. Financial and economic mechanism of effective functioning of agricultural enterprises of Ukraine [Finansovo-ekonomichnyj mehanizm efektyvnogo funkcionuvannja agrarnyh pidpryjemstv Ukrai'ny]. (Ed.). Kyiv: CPU "KOMPRYNT", 2017. p. 249-265. 